University of Nebraska - Lincoln

DigitalCommons@University of Nebraska - Lincoln

\title{
Coccidia (Apicomplexa: Eimeriidae) Infecting Cricetid Rodents from Alaska, U.S.A., and Northeastern Siberia, Russia, and Description of a New Eimeria Species from Myodes rutilus, the Northern Red-Backed Vole
}

\author{
Donald W. Duszynski \\ University of New Mexico, eimeria@unm.edu \\ Andrew J. Lynch \\ University of New Mexico \\ Joseph A. Cook \\ University of New Mexico
}

Follow this and additional works at: https://digitalcommons.unl.edu/parasitologyfacpubs

Part of the Parasitology Commons

Duszynski, Donald W.; Lynch, Andrew J.; and Cook, Joseph A., "Coccidia (Apicomplexa: Eimeriidae) Infecting Cricetid Rodents from Alaska, U.S.A., and Northeastern Siberia, Russia, and Description of a New Eimeria Species from Myodes rutilus, the Northern Red-Backed Vole" (2007). Faculty Publications from the Harold W. Manter Laboratory of Parasitology. 144.

https://digitalcommons.unl.edu/parasitologyfacpubs/144

This Article is brought to you for free and open access by the Parasitology, Harold W. Manter Laboratory of at DigitalCommons@University of Nebraska - Lincoln. It has been accepted for inclusion in Faculty Publications from the Harold W. Manter Laboratory of Parasitology by an authorized administrator of DigitalCommons@University of Nebraska - Lincoln. 


\title{
Coccidia (Apicomplexa: Eimeriidae) Infecting Cricetid Rodents from Alaska, U.S.A., and Northeastern Siberia, Russia, and Description of a New Eimeria Species from Myodes rutilus, the Northern Red-Backed Vole
}

\author{
D. W. Duszynski, ${ }^{1}$ A. J. Lynch, And J. A. CoOK \\ Department of Biology and Museum of Southwestern Biology, The University of New Mexico, \\ Albuquerque, New Mexico 87131, U.S.A. (e-mail: eimeria@unm.edu)
}

ABSTRACT: During the summers of 2000, 2001, and 2002, 1,950 fecal samples from 4 families, 10 genera, and 16 species of rodents in Alaska, U.S.A. $(N=1,711)$, and Siberia, Russia $(N=239)$ were examined for coccidia (Apicomplexa: Eimeriidae). The 4 families sampled were Dipodidae (jumping mice), Erethizontidae (New World porcupines), Muridae (mice, rats), and Cricetidae (voles, lemmings). Nineteen oocyst morphotypes were observed, of which 10 were consistent with descriptions of known coccidia species from murid hosts, 8 were similar to oocysts described previously from other genera than those in which they are found here (and are called Eimeria species 1-8), and 1 is described as new. In the Dipodidae, all from Alaska, 0/15 Zapus hudsonius had coccidian oocysts in their feces when examined. In the Erethizontidae, all from Alaska, 0/5 Erethizon dorsatum had oocysts when examined. In the Muridae, all from Russia, 0/5 Apodemus peninsulae had oocysts when examined. In the Cricetidae from Alaska, we found the following infections: 15/72 (21\%) Lemmus trimucronatus (Eimeria spp. 3, 4, 5); 10/29 (34\%) Microtus longicaudus (Eimeria saxei, Eimeria wenrichi); 41/88 (47\%) Microtus miurus (Eimeria coahiliensis, Eimeria ochrogasteri, Eimeria saxei, Eimeria wenrichi); 278/405 (68\%) Microtus oeconomus (E. ochrogasteri, E. saxei, E. wenrichi); 116/159 (73\%) Microtus pennsylvanicus (E. saxei, E. wenrichi); 9/52 (17\%) Microtus xanthognathus (E. wenrichi); 218/699 (31\%) Myodes rutilus (Eimeria cernae, Eimeria gallati, Eimeria marconii, Isospora clethrionomydis, Isospora clethrionomysis, and a new Eimeria species); 34/187 (18\%) Synaptomys borealis (Eimeria spp. 6, 7 , 8, Eimeria synaptomys). In the Cricetidae from Siberia, we found the following infections: 5/24 (21\%) Alticola macrotis (Eimeria spp.1, 2); 0/5 Dicrostonyx torquatus; 1/11 (9\%) Lemmus lemmus (Eimeria sp. 3); 30/48 (52\%) Mi.oeconomus (E. saxei, E. wenrichi); 5/53 (9\%) Myodes rufocanus (E. cernae, E. gallati, I. clethrionomydis, the new Eimeria sp.); 21/85 (25\%) Myodes rutilus (E. cernae, E. gallati, E. marconii, the new Eimeria sp.); 0/8 Myopus schisticolor. Oocysts of the new species, found in both My. rutilus (Alaska, Siberia) and My. rufocanus (Siberia), are ellipsoidal with a striated outer wall and measured $30.6 \times 20.5(27-33 \times 19-23) \mu \mathrm{m}$; micropyle and oocyst residuum absent, but a polar granule is present. Sporocysts are ellipsoidal, $14.5 \times 9.1(13-16 \times 8-10) \mu \mathrm{m}$; Stieda body, sub-Stieda body and sporocyst residuum are present.

KEY WORDS: Apicomplexa, Eimeriidae, Eimeria, Isospora, coccidia, Rodentia, Cricetidae, Alticola, Dicrostonyx, Lemmus, Microtus, Myodes, Myopus, Erethizontidae, Erethizon, Dipodidae, Zapus, Muridae, Apodemus, Siberia, Russia, Alaska, U.S.A.

Over 3 summer field seasons (2000-2002) rodents were collected in Alaska, U.S.A., and northeastern Siberia, Russia, and examined for parasites as part of the Beringia Co-evolution Project (BCP) (see Hoberg et al., 2003). Rarely is there an opportunity to conduct a parasite survey of this magnitude. The main objective of our part in the overall study was to identify the coccidia found in all host animals collected and answer 2 simple questions: 1) Do the same host family, genera, and/or species on different continents share the same coccidia species? 2) How are the parasite assemblages similar or different among closely related hosts? The answers may help us understand the distributions of each parasite species across this large geographic area that was once continuous but is now separated by the Bering Strait.

\footnotetext{
${ }^{1}$ Corresponding author.
}

\section{MATERIALS AND METHODS}

Rodents were collected (Cook et al., 2005) using a variety of traps or firearms (University Alaska-Fairbanks animal protocol 99-012 and 01-016 and the Idaho State University animal protocol 03-02-442). Rodents were collected from 10 sites in Alaska, U.S.A., and 4 sites in northeastern Siberia, Russia. The Alaskan sites included 2 regional sites in western Alaska near Nome and Kotzebue, 3 national preserves: Bering Land Bridge, Yukon-Charley Rivers, and Noatak, 4 national parks: Denali, Gates of the Arctic, Kobuk Valley, and Wrangell-Saint Elias, and 1 national monument: Cape Krusenstern. The 4 regions sampled in northeastern Siberia were the Omolon, Anadyr, and Kolyma River basins and the Providenya Oblast. Animals were dissected $10 \mathrm{~min}$ or less after death, their intestinal tract was removed, and feces were preserved in $2.5 \%$ (w/v) aqueous potassium dichromate $\left(\mathrm{K}_{2} \mathrm{Cr}_{2} \mathrm{O}_{7}\right)$ solution. Fecal-dichromate solutions were brought to the University of New Mexico within $1 \mathrm{mo}$ after collection and stored at $4^{\circ} \mathrm{C}$. Within $6 \mathrm{mo}$ after collection, oocysts were isolated, measured, and photographed as described by Duszynski and Wilber (1997). Photosyntypes (Duszynski, 1999) of sporulated oocysts of the new eimerian were submitted to the United 
Table 1. Prevalence of coccidia from rodents collected in the summers of 2000-2002, from Siberia, Russia, and Alaska, U.S.A.

\begin{tabular}{|c|c|c|c|}
\hline Locality & Family/genus/species & No. infected/no. collected (\%) & Eimeria and Isospora species found \\
\hline \multirow[t]{10}{*}{ Russia } & Cricetidae $(N=239)$ & & \\
\hline & Alticola macrotis & $5 / 24(21)$ & E. sp. $1, E$. sp. 2 \\
\hline & Dicrostonyx torquatus & $0 / 5$ & - \\
\hline & Lemmus lemmus & $1 / 11(9)$ & E. sp. 3 \\
\hline & Microtus oeconomus & $30 / 48(52)$ & E. saxei, E. wenrichi \\
\hline & Myodes rufocanus & $5 / 53(9)$ & E. cernae, E. gallatii, E. rutilus, I. clethrionomydis \\
\hline & My. rutilus & $21 / 85(25)$ & E. cernae, E. gallatii, E. marconii, E. rutilus \\
\hline & Myopus schisticolor & $0 / 8$ & - \\
\hline & Muridae $(N=5)$ & & \\
\hline & Apodemus peninsulae & $0 / 5$ & - \\
\hline \multirow[t]{14}{*}{ U.S.A. } & Erethizontidae $(N=5)$ & & \\
\hline & Erethizon dorsatum & $0 / 5$ & - \\
\hline & Cricetidae $(N=1,691)$ & & \\
\hline & L. trimucronatus & $15 / 72(21)$ & E. sp. 3, E. sp. 4, E. sp. 5 \\
\hline & Mi. longicaudus & $10 / 29(34)$ & E. saxei, E. wenrichi \\
\hline & Mi. miurus & $41 / 88(47)$ & E. coahuiliensis, E. ochrogasteri, E. saxei, E. wenrichi \\
\hline & Mi. oеconomus & $278 / 405(68)$ & E. ochrogasteri, E. saxei, E. wenrichi \\
\hline & Mi. pennsylvanicus & $116 / 159(73)$ & E. saxei, E. wenrichi \\
\hline & Mi. xanthognathus & $9 / 52(17)$ & E. wenrichi \\
\hline & My. rutilus & $218 / 699(31)$ & $\begin{array}{l}\text { E. cernae, E. gallatii, E. marconii, E. rutilus, } \\
\text { I. clethrionomydis, I. clethrionomysis }\end{array}$ \\
\hline & Synaptomys borealis & $34 / 187(18)$ & E. sp. 6, E. sp. 7, E. synaptomys, E. sp. 8 \\
\hline & Dipodidae $(N=15)$ & & \\
\hline & Zapus hudsonius & $0 / 15$ & - \\
\hline & 4 families, 16 species & $783 / 1,950(40)$ & 17 Eimeria, 2 Isospora species \\
\hline
\end{tabular}

States National Parasite Collection (USPNC) in Beltsville, Maryland, U.S.A. (see Bandoni and Duszynski, 1988) as were photomicrographs of other forms (e.g., photoneotypes) when appropriate. Symbiotype host specimens (Frey et al., 1992; Brooks, 1993), in which all oocyst species/forms were seen and identified here, are maintained in the University of Alaska Museum of the North (UAM) All measurements are presented in $\mu \mathrm{m}$, and we used the abbreviations of Wilber et al. (1998) as follows: length (L), width (W), micropyle (M), oocyst residuum (OR), polar granule (PG), Stieda body (SB), sub-Stieda body (SSB), sporocyst residuum (SR), sporozoite (SZ), and refractile body (RB).

Recently Wilson and Reeder (2005) made substantial changes in the nomenclature of the mammalian order Rodentia. Principally, the long-standing vole genus, Clethrionomys, became a junior synonym of Myodes. Since we have 2 infected host genera that we refer to repeatedly, and that both begin with the same letter, we use the following genus abbreviations to avoid confusion; Mi. for Microtus and My. for Myodes.

\section{RESULTS}

In all, 1,950 rodents were collected representing 4 families, 10 genera, and 16 species in Alaska, U.S.A. $(N=1,711)$ and Russia $(N=239)$. The families sampled were Dipodidae (jumping mice), Erethizontidae (New World porcupines), Muridae (mice, rats), and Cricetidae (voles and lemmings).

Wilson and Reeder (2005) list 6 subfamilies in the
Dipodidae. In our study only 1 subfamily, Zapodinae, was sampled with all 15 specimens of Zapus hudsonius Zimmerman, 1780, the meadow jumping mouse, negative for coccidian oocysts.

There are 5 genera and 16 species in the Erethizontidae. In this study only 5 specimens of Erethizon dorsatum, L., 1758, the North American porcupine, were sampled; all 5 were negative.

We collected only 5 Apodemus peninsulae Thomas, 1907, the Korean field mouse, from the Muridae (subfamily Murinae), and all were negative.

Wilson and Reeder (2005) list 6 subfamilies of cricetids. We collected 13 host species in 7 genera within the subfamily Arvicolinae, which included 8 species of "voles" and 5 species of "lemmings." Lemmings and voles comprise an enigmatic group of arvicolid rodents that, as yet, have unresolved phylogenetic relationships (see Discussion). Here we list the 19 putative coccidia species we found in vole genera first, followed by the coccidia found in lemming hosts (see Table 1). For the new eimerian, we give a complete description following the format of Wilber et al. (1998). For the coccidia that either have been recorded from a host genus or species before, or those that resemble strongly species described from other host genera, we provide only 
a taxonomic summary and any discrepancies from, or changes to, the original description.

\section{Voles \\ Eimeria sp. 1}

Host: Alticola macrotis (Radde, 1862), no common name recorded.

Other hosts: None, see Remarks, below.

Collected: V. B. Fedorov, K. E. Galbreath, 26 July 2002.

Locality: Asia: Russia, northern Siberia, Providenya Oblast, Chukotka, Ulhum River, $15 \mathrm{~km} \mathrm{~W}$ of Chaplino Village $\left(64^{\circ} 25^{\prime} \mathrm{N}, 172^{\circ} 32^{\prime} \mathrm{W}\right)$.

Geographic distribution: Asia: Russia.

Prevalence: 1/24 (4\%) (Table 1).

Material deposited: Symbiotype host, UAM 83818 (IF 7551).

Remarks: Svanbaev (1956) was the first to examine a member of this host genus, Alticola strelzowi (Kastchenko, 1899), for coccidia and reported finding Eimeria arvicolae Galli-Valerio, 1905, originally described from the snow vole, Microtus nivalis (Martins, 1842), in western Kazakhstan. Later Svanbaev (1958) reported E. arvicolae in 4/43 (9.3\%) A. strelzowi in the Karaganda Region of central Kazakhstan. The oocysts we found in A. macrotis $(29 \times 21$ [26-31 $\times 19-23])$ differed from the spherical oocysts of E. arvicolae (14-18 in diameter). In 1980 Dzerzhinskii and Svanbaev (1980) reported finding oocysts they called Eimeria argentata in a species of Alticola from the Altai Mountains in Kazakhstan, but did not describe the oocysts or provide any images. Thus, this name becomes a nomen nudum (fails to conform to Article 12 of the International Code of Zoological Nomenclature). Finally, Levine and Ivens (1990) provided the name Eimeria bassagensis to the form earlier called E. arvicolae by Svanbaev $(1958,1969)$. The sporulated oocysts we saw in A. macrotis differ in shape (broadly ellipsoidal vs. ovoidal), size $(29 \times 21$ vs. $25 \times 22)$, and L/W ratio (1.4 vs. 1.1) from those of E. bassagensis and have sporocysts with a SB and $\mathrm{SSB}$, which those of E. bassagensis lack. Oocysts of our species closely resemble those of Eimeria subsimi Vance and Duszynski, 1985, in Microtus mexicanus Goldman, 1938, from Mexico (Vance and Duszynski, 1985). Oocyst and sporocyst size means are slightly larger than those of E. subsimi $(25 \times 19$ and $14 \times 7$ ), but the oocysts of both lack a $\mathrm{M}$ and OR, possess a PG, and their sporocysts contain both SB and SSB and a membrane-bound, faceted SR. Rather than suggesting the form we saw can cross generic boundaries and call it E. subsimi, or assuming that it can't and call it a new species, we believe it best at this time to document its presence in A. macrotis and do neither.

A line drawing and photomicrographs of sporulated oocysts of E. subsimi already have been published (Vance and Duszynski, 1985), and photosyntypes are in the USNPC as \#88512. We did not feel it necessary to submit phototypes of species with uncertain taxonomic status to the USNPC (Eimeria spp. 1-8).

\section{Eimeria sp. 2}

Host: Alticola macrotis (Radde, 1862), no common name recorded.

Other hosts: None, see Remarks under Eimeria sp. 1 and below.

Collected: V. B. Fedorov, K. E. Galbreath, 16 August 2002.

Locality: Asia: Russia, northern Siberia, Providenya Oblast, Chukotka, $10 \mathrm{~km} \mathrm{SW}$ of Yanrakynnot Village $\left(64^{\circ} 52^{\prime} \mathrm{N}, 172^{\circ} 40^{\prime} \mathrm{W}\right)$.

Geographic distribution: Asia: Russia, Providenya Oblast and Kolyma River Basin.

Prevalence: 4/24 (17\%) (Table 1).

Material deposited: Symbiotype host, UAM 84096 (IF 7831).

Remarks: The oocysts we saw differed in size and other qualitative features from both Eimeria sp. 1 and E. bassagensis noted above. They closely resemble sporulated oocysts first described as "Eimeria wenrichi species A" by Saxe et al. (1960) (see Vance and Duszynski, 1985), from Microtus pennsylvanicus Ord, 1815, in Pennsylvania. Our oocyst $(22 \times 17$ [19.5-23 $\times 16-19])$ and sporocyst $(12 \times 7$ [11-12 $\times$ 7-8]) sizes were slightly larger than those in the original description $(19 \times 14$ and $10 \times 6)$, but all unique qualitative features (e.g., small dark SB, faceted SR) were consistent with the original description. Because of rapid host speciation documented by Conroy and Cook (1999), this eimerian may be able to infect multiple host genera; however, as noted in reasons given for Eimeria sp. 1 (above), we believe it best at this time only to document its presence in A. macrotis. 
A line drawing (Saxe et al., 1960) and photomicrograph of sporulated oocysts (Vance and Duszynski, 1985) of E. wenrichi have already been published, and photosyntypes are in the USNPC as \#88517.

\section{Eimeria cernae Levine and Ivens, 1965}

(Fig. 1)

Type host: Myodes (Clethrionomys) glareolus (Shreber, 1780), common red-backed vole.

Other hosts: Myodes (Clethrionomys) rufocanus Sundevall, 1846 (Russia), Myodes (Clethrionomys) rutilus (Pallas, 1779) (Alaska, Russia), both in this study (Table 1).

Collected (this study): A. M. Runck, 13 July 2001.

Type locality: Europe: Czech Republic.

Locality (this study): North America, U.S.A., Alaska, Noatak National Preserve, west bank of Situkuyok River $\left(67^{\circ} 12.3^{\prime} \mathrm{N}, 163^{\circ} 9.7^{\prime} \mathrm{W}\right)$.

Geographic distribution: Europe: Czech Republic; Asia: Russia, Siberia; North America: U.S.A., Alaska.

Prevalence: Unknown in the type host; $1 / 53(<2 \%)$ in My. rufocanus from Russia; 19/85 (22\%) in My. rutilus from Russia; 181/699 (26\%) in My. rutilus from Alaska (Table 1).

Sporulation: 2-4 days (Lewis and Ball, 1982).

Prepatent period: 6 days (Lewis and Ball, 1982).

Patent period: 4-6 days.

Site of infection: Epithelial cells of the cecum, colon, and rectum.

Endogenous stages: Lewis and Ball (1982) described 3 meront generations and the macro- and microgamonts and gametes from My. glareolus.

Material deposited: We deposited a photoneotype (see Duszynski, 1999) of a sporulated oocyst from My. rutilus (Alaska) in the USNPC as \#99497. Symbiotype host (this study), UAM 56126 (AF 46214).

Remarks: The morphology of sporulated oocysts we studied from My. rufocanus and My. rutilus fits well with the composite description of E. cernae provided in the studies by Levine and Ivens (1990) and Lewis and Ball $(1982,1983)$. Our oocyst and sporocyst size ranges $(17.5-22 \times 14-18.5$ and $9-11 \times 5-7)$ overlap those $(13-23 \times 11-17$ and $9-15 \times 4-7)$ given by Levine and Ivens (1990), but they did not give mean size measurements. Our quantitative data also are similar to the means provided by Lewis and Ball (1982) from My. glareolus in England $(20 \times 17$ and $10 \times 6$ vs. $20 \times 16$ and $12 \times 7$ ). However, we observed 2 oocyst walls while all other descriptions of this coccidium only observed 1 . Duszynski (2002) suggested that reports of oocysts having only 1 wall likely are in error and should be viewed cautiously when using older descriptions. Eimeria cernae was reported previously in My. rutilus from the Taimyr Peninsula (Arnastauskiene, 1977). Its recovery from My. rutilus in Alaska is a new geographic record, while its recovery from My. rufocanus in Russia is a new host record.

Line drawings (Levine and Ivens, 1965; Lewis and Ball, 1982, 1983) and a photomicrograph of a sporulated oocyst (Lewis and Ball, 1983) of E. cernae already have been published, and these can be compared to our Figure 1, which we have deposited as a photoneotype, as noted above.

\section{Eimeria coahuiliensis Vance and Duszynski, 1985}

Type host: Microtus mexicanus subsimus Goldman, 1938, meadow vole.

Other hosts: Mi. miurus (Table 1).

Collected (this study): V. B. Fedorov, A. Fedorov, E. C. Waltari, B. Wagner, 25 July 2001.

Type locality: North America: Mexico, Coahuila, $14.8 \mathrm{~km}$ E of San Antonio de las Alazanas.

Locality (this study): North America: U.S.A., Alaska, Noatak National Preserve, Misheguk Mountain $\left(68^{\circ} 28^{\prime} \mathrm{N}, 161^{\circ} 28^{\prime} \mathrm{W}\right)$.

Geographic distribution: North America: Mexico, Coahuila; U.S.A.: Alaska.

Prevalence: 2/22 (9\%) Mi. m. subsimus (type host); 2/88 (2\%) Mi. miurus from Alaska (Table 1).

Sporulation: Unknown.

Prepatent and patent periods: Unknown.

Site of infection: Unknown, oocysts recovered from feces.

Endogenous development: Unknown. 


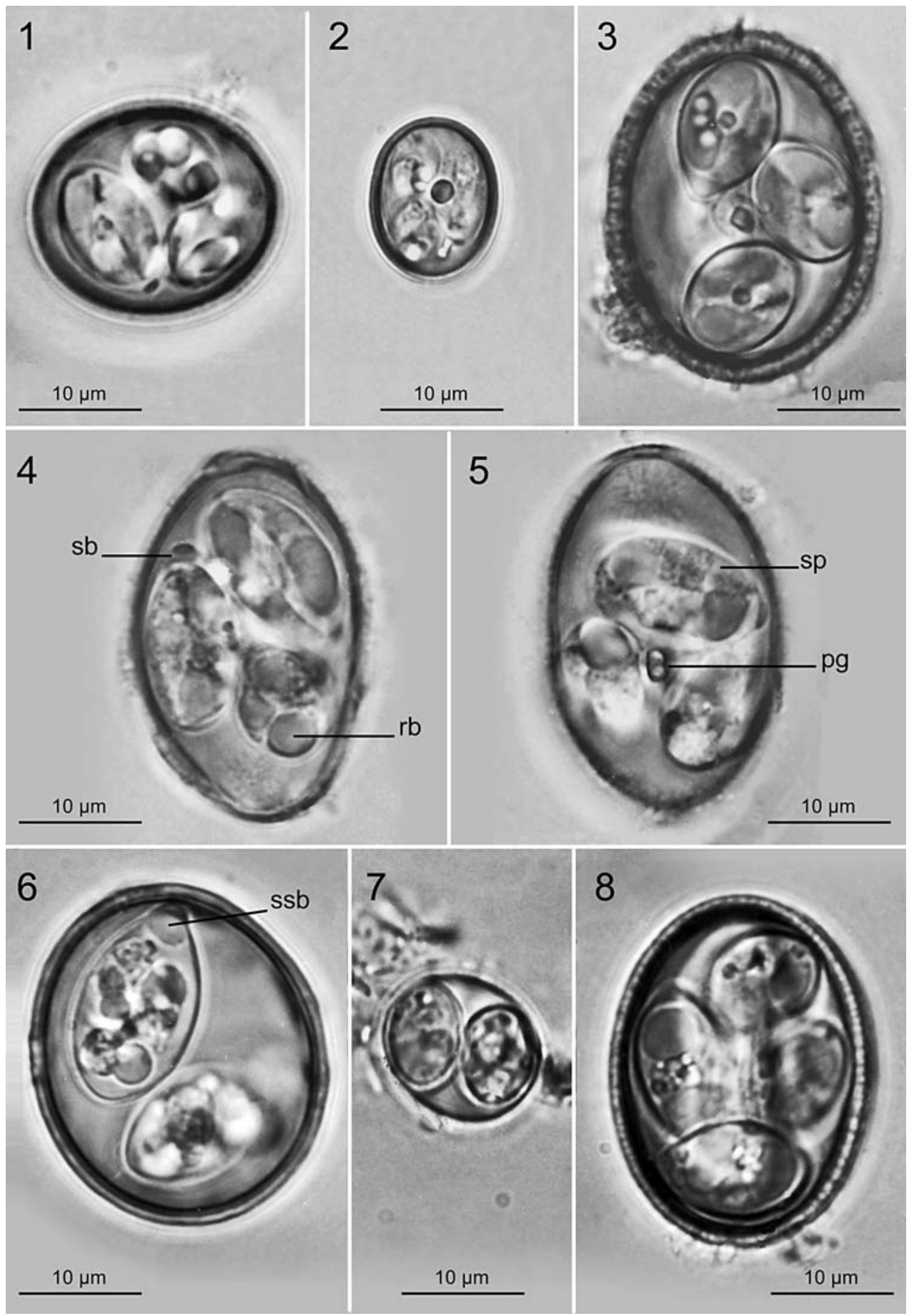

Figures 1-8. Photomicrographs of sporulated oocysts of Eimeria and Isospora spp. from rodents from Alaska and Russia. 1. Eimeria cernae from Myodes rutilus from Alaska. 2. Eimeria marconii from My. rutilus from Alaska. 3. Eimeria ochrogasteri from Microtus miurus from Alaska. 4, 5. Eimeria. rutilus from My. rutilus from Alaska. 6. Isospora clethrionomydis from My. rutilus from Alaska. 7. Isospora clethrionomysis from My. rutilus from Alaska. 8. Eimeria synaptomys from $S$. borealis from Alaska (sb, Stieda body at tip of sporocyst; rb, refractile in sporozoite; sp, sporozoite; pg, polar granule in oocyst; ssb, sub-Stieda body below sb). 
Material deposited: A photosyntype is deposited in the USNPC as \#88509. Symbiotype host (this study): UAM 56682 (AF 48384).

Remarks: Sporulated oocysts $(N=25)$ from $M i$. miurus were $32.3 \times 22.0(29-35 \times 19.5-26)$, somewhat larger than those in the original description, $29.6 \times 19.6(27-34 \times 18-22)$, but the L/W ratios, 1.5 , were the same, and all other features of the oocysts and sporocysts were the same. Line drawings and photomicrographs of oocysts are in the original description. This report represents new host and locality records for E. coahuiliensis.

\section{Eimeria gallatii Straneva and Kelly, 1979}

Type host: Myodes (C.) gapperi (Vigors, 1830), redbacked vole.

Other hosts: My. rufocanus (Russia), My. rutilus (Alaska, Russia), Table 1.

Collected (this study): S. Kutz, A. A. Tsvetkova, A. A. Eddingsaas, M. McCain, 19 July 2001.

Type locality: North America: U.S.A., Pennsylvania, Indiana County, Brush Valley.

Locality (this study): North America: U.S.A., Alaska, Wrangell-St. Elias National Preserve, Nabesna, Chisana $\left(62^{\circ} 3.9^{\prime} \mathrm{N}, 142^{\circ} 2.8^{\prime} \mathrm{W}\right)$.

Geographic distribution: North America: U.S.A., Pennsylvania, Alaska; Asia: Russia, Siberia.

Prevalence: 1/15 (7\%) in My. gapperi (type host); 4/53 (7.5\%) in My. rufocanus from Russia; 1/85 (1\%) in My. rutilus from Russia; 16/699 (2\%) in My. rutilus from Alaska (Table 1).

Sporulation: 7 days at $22-25^{\circ} \mathrm{C}$ (Straneva and Kelley, 1979).

Prepatent and patent periods: Unknown.

Site of infection: Unknown, oocysts recovered from fecal material.

\section{Endogenous stages: Unknown.}

Material deposited: Symbiotype host (this study), UAM 57764 (AF 54520).

Remarks: The oocysts and sporocysts we studied and measured resembled E. gallatii, first described from a red-backed vole in Pennsylvania, in most ways except that those in the original description are slightly smaller $(27.7 \times 19.3$ and $13.5 \times 8.8)$ than the ones we measured $(N=50 ; 30.6 \times 20.5[29-33 \times 19$ 23] and $14.5 \times 9.1$ [13-16 $\times 8-10])$. All qualitative features are the same. The only uncertainty is whether or not a M really exists in the oocyst wall or whether the wall thins so much at the flattened pole of the oocyst to give the impression of a $\mathrm{M}$ when the osmotic concentration of the flotation fluid causes it to indent slightly. Unfortunately all our infected samples were discarded during a laboratory renovation after measurements were made, but before we were able to make photomicrographs of this species to deposit in the USNPC. Only a line drawing exists in the original description by Straneva and Kelley (1979).

\section{Eimeria marconii Straneva and Kelley, 1979} Fig. 2

Type host: Myodes (C.) gapperi (Vigors, 1830), southern red-backed vole.

Other hosts: My. rutilus (Russia, Alaska), Table 1.

Collected (this study): A. M. Runck, 21 July 2001.

Type locality: North America: U.S.A., Pennsylvania, Indiana County, Brush Valley.

Locality (this study): North America: U.S.A., Alaska, Cape Krusenstern National Monument, Red Dog Mine Road $\left(67^{\circ} 44.97^{\prime} \mathrm{N}, 163^{\circ} 36.56^{\prime} \mathrm{W}\right)$.

Geographic distribution: North America: U.S.A., Pennsylvania, Alaska; Asia, Russia, Siberia.

Prevalence: 1/15 (7\%) in My. gapperi (type host); 1/85 (1\%) in My. rutilus from Russia, and 40/699 (6\%) in My. rutilus from Alaska (Table 1).

Sporulation: Unknown.

Prepatent and patent periods: Unknown.

Site of infection: Unknown, oocyst recovered from feces.

\section{Endogenous stages: Unknown.}

Material deposited: A photoneotype (see Duszynski, 1999) of a sporulated oocyst from My. rutilus (Alaska) is deposited in the USNPC as \#99498. Symbiotype host (this study), UAM 55963 (AF 46245).

Remarks: The morphology of oocysts from My. rutilus in Alaska is similar to the description 
provided by Straneva and Kelley (1979) of E. marconii described from My. gapperi in Pennsylvania. Oocyst and sporocyst sizes were similar to those in the original description $(13 \times 10$ and $7 \times$ 4 vs. $13 \times 11$ and $8 \times 4$ ). Unique qualitative features (e.g., single PG, small, dark SB, membrane-bound SR) were consistent with the original description. The recovery of E. marconii from My. rutilus in Russia and Alaska is a new host and geographic record for this parasite. A line drawing of the sporulated oocyst appears in the description by Straneva and Kelley (1979).

\section{Eimeria ochrogasteri Ballard, 1970 Fig. 3}

Type host: Microtus ochrogasteri Wagner, 1842, prairie vole.

Other hosts: Mi. mexicanus fulviventer, Mi. m. mexicanus, Mi. p. pennsylvanicus (Vance and Duszynski, 1985), Mi. miurus, Mi. oeconomus (Table 1).

Collected (this study): V. B. Fedorov, 26 July 2001.

Type locality: North America: U.S.A., Colorado, Weld County, Black Hollow west of Ault.

Locality (this study): North America: U.S.A., Alaska, Noatak National Preserve, $8 \mathrm{~km}$ w of Copter Peak $\left(68^{\circ} 28^{\prime} \mathrm{N}, 161^{\circ} 28^{\prime} \mathrm{W}\right)$.

Geographic distribution: North America: U.S.A., Alaska, Colorado, Massachusetts; Mexico: Mexico, Oaxaca.

Prevalence: 1/71 (1\%) Mi. ochrogaster (type host); $3 / 26(11.5 \%)$ in $M i$. m. fulviventer from Oaxaca; $1 / 14$ (14\%) in Mi. m. mexicanus from Mexico; 1/11 (9\%) in Mi. p. pennsylvanicus from Massachusetts (Vance and Duszynski, 1985); 1/88 (1\%) in Mi. miurus and $2 / 405(0.5 \%)$ in $M i$. oeconomus, both from Alaska (Table 1).

Sporulation: Up to 9 days at $20^{\circ} \mathrm{C}$.

Prepatent and patent periods: Unknown.

Site of infection: Unknown, oocysts recovered from feces.

\section{Endogenous development: Unknown.}

Material deposited: We deposited a photoneotype (see Duszynski, 1999) of a sporulated oocyst from Mi. miurus (Alaska) in the USNPC as \#99499.

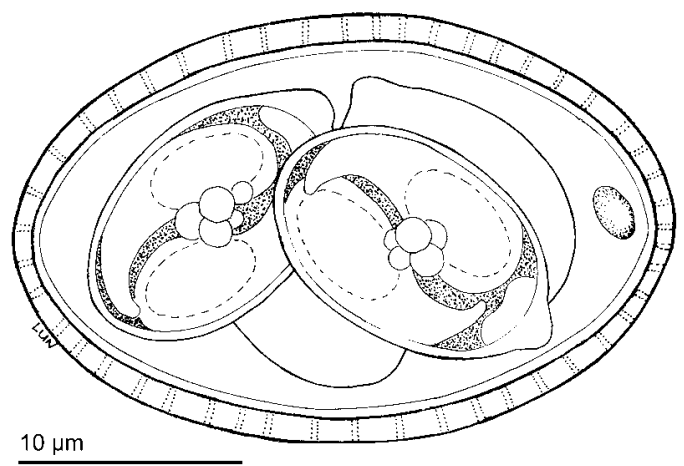

Figure 9. Composite line drawing of a sporulated oocyst of Eimeria rutilus.

Symbiotype host (this study), UAM 56698 (AF 48417).

Remarks: The morphology of oocysts from Mi. oeconomus and Mi. miurus in Alaska is similar to the description of E. ochrogasteri provided by Ballard (1970) from Mi. ochrogaster in Colorado. Oocysts $(N=11)$ from Mi. miurus were $28.6 \times 23.4$ (26-32 $\times 22-25)$, and those from Mi. oeconomus $(N=25)$ were $29.0 \times 23.4(26-32 \times 22-25)$, while those from Mi. ochrogaster $(N=100)$ were $24.0 \times$ $20.5(18-29 \times 16.5-24)$; similarly, sporocysts $(N=$ 11) from Mi. miurus $(13.1 \times 8.7$ [12-14 × 8-9]) and from Mi. oeconomus $(N=25$ : $13.2 \times 8.6$ [12-14 $\times 8$ 9]) were slightly larger than those in the original description $(N=50: 12.3 \times 8.2[11-14 \times 7-9])$. Ballard (1970) said that the average L/W ratio of his oocysts was 1.7, but this is incorrect; his data show a L/W of $1.2(24 / 20.5)$, as do ours. The qualitative features (e.g., thick oocyst wall, variable OR, "capped" SB, and dispersed SR) we saw in oocysts from Alaskan microtines were similar to those in the original description. The recovery of E. ochrogasteri here represent new host records and a new geographic record. A line drawing of the sporulated oocyst appears in the description by Ballard (1970).

\section{Eimeria rutilus $\mathrm{n} . \mathrm{sp}$.}

Figs. 4, 5, 9

Description of sporulated oocyst: Oocyst shape: ellipsoidal; number of walls: 2; wall thickness: $\sim 1.75$; wall characteristics: thinner at ends, outer slightly striated, $3 / 4$ of total width, inner, membranous; $\mathrm{L} \times \mathrm{W}(N=50): 30.6 \times 20.5(27-33 \times 19-23)$; L/W ratio: 1.5 (1.4-1.7); M: absent; OR: absent; PG: 
present, single elliptical body, $\sim 3 \times 2$. Distinctive features of oocyst: large, ellipsoid shape with walls that become thinner at the 2 ends.

Description of sporocyst and sporozoites: Sporocyst shape $(N=50)$ : ellipsoidal; $\mathrm{L} \times \mathrm{W}: 14.5 \times 9.1$ $(13-16 \times 8-10) ; \mathrm{L} / \mathrm{W}$ ratio: 1.6 (1.4-1.9); SB: present, dark, 3 times wider than high; SSB: present, colorless, twice as wide as SB, but just as high; PSB: absent; SR: present; SR characteristics: large refractile granules congregated in the center of the sporocyst; SZ: comma-shaped with one large, long $\mathrm{RB}, \sim 7-3$. Distinctive features of sporocyst: presence of SB/SSB complex, SR with large granules, large RB.

\section{Taxonomic summary}

Type host: Myodes (C.) rutilus (Pallas, 1779), northern red-backed vole.

Other host: My. rufocanus (Russia), Table 1.

Collected: V. B. Fedorov, 15 July 2001.

Type locality: North America: U.S.A., Alaska, Noatak National Preserve, near Sidik Lake $\left(68^{\circ} 08^{\prime} \mathrm{N}, 158^{\circ} 59^{\prime} \mathrm{W}\right)$.

Geographic distribution: Asia: Russia, northeastern Siberia; North America: U.S.A., Alaska.

Prevalence: 1/85 (1\%) in My. rutilus (Russia); 16/699 (2\%) in My. rutilus (Alaska); 3/53 (6\%) in My. rufocanus (Russia).

Sporulation: Unknown.

Prepatent and patent periods: Unknown.

Site of infection: Unknown, oocysts recovered from feces.

Endogenous stages: Unknown.

Material deposited: A photosyntype of a sporulated oocyst from the symbiotype host is deposited in the USNPC as \#99500. Symbiotype host, UAM 56279 (AF 48238, male).

Remarks: Sporulated oocysts of E. rutilus resemble those of Eimeria species identified by Straneva and Kelley (1979) and Vance and Duszynski (1985): E. gallatii from My. gapperi and E. coahuiliensis from Mi. mexicanus, respectively. The oocyst and sporocyst sizes are similar $(31 \times 21$ and $15 \times 9$ vs. $28 \times 19$ and $14 \times 9$ [Straneva and Kelley, 1979] vs. $30 \times 20$ and $14 \times 9$ [Vance and Duszynski, 1985]). All 3 species are characterized by having a SB and a SR composed of loose granules aggregated in the center of the sporocyst, although at times the SR in $E$. rutilus appears to be membrane bound. There are 2 structures that differentiate these 3 species. Both $E$. gallatii and $E$. coahuiliensis have a $\mathrm{M}$, while $E$. rutilus does not. We also identified a SSB in $E$. rutilus, while the other 2 lack this structure.

Etymology: The nomen triviale is derived from the specific name of the type host, rutilus.

\section{Eimeria saxei Vance and Duszynski, 1985}

Type host: Microtus pennsylvanicus Ord, 1815, meadow vole.

Other hosts: Mi. californicus sactidiegi, Mi. longicaudus, Mi. mexicanus fulviventer, Mi. m. mexicanus, Mi. m. subsimus, Mi. oregoni oregoni (Vance and Duszynski, 1985), Mi. miurus, Mi. oeconomus (Table 1).

Collected (this study): S. O. MacDonald, A. N. Lazutkin, A. J. Lynch, S. Runck, K. Gamblin, L. B. Barrelli, N. MacDonald, N. I. MacDonald, 9 August, 2001.

Type locality: North America: U.S.A., Pennsylvania.

Locality (this study): North America: U.S.A., Alaska, Yukon-Charley Rivers National Preserve, Charley River $\left(65^{\circ} 21.3^{\prime} \mathrm{N}, 142^{\circ} 57.5^{\prime} \mathrm{W}\right)$.

Geographic distribution: North America: U.S.A., Alaska, California, Pennsylvania, Washington; Mexico: Coahuila, Mexico, Oaxaca; Asia: Russia, Siberia.

Prevalence: 1/1 (100\%) in Mi. pennsylvanicus from Pennsylvania (type host); 1/3 (33\%) in Mi.c. sactidiegi from California; $3 / 29$ (10\%) in Mi. longicaudus from Alaska (Table 1); 1/26 (4\%) in Mi.m. fulviventer from Oaxaca; $1 / 14$ (7\%) in Mi.m. mexicanus from Mexico; $3 / 48(6 \%)$ in Mi. m. subsimus from Coahuila; $1 / 4$ $(25 \%)$ in Mi. o. oregoni from Washington; $2 / 88$ (2\%) in Mi. miurus from Alaska (Table 1); $2 / 48$ (4\%) in Mi. oeconomus from Siberia (Table 1); 18/405 (4\%) in Mi. oeconomus from Alaska (Table 1) .

Sporulation: 2-3 days at $24-27^{\circ} \mathrm{C}$.

Prepatent and patent periods: Unknown.

Site of infection: Unknown, oocysts recovered from feces.

Endogenous development: Unknown. 
Material deposited: A photosyntype is deposited in the USNPC as \#88510. Symbiotype host (this study), UAM 57278 (AF 52605).

Remarks: Originally described as "E. wenrichi species B" by Saxe et al. (1960), Vance and Duszynski (1985) renamed this species as E. saxei. The morphology of oocysts from Microtus species in Alaska and Russia is similar to both the original description for E. saxei from Mi. pennsylvanicus and the redescription by Vance and Duszynski (1985) from Mi. mexicanus, Mi. oregoni, and Mi. californicus. Oocysts we measured $(N=25)$ from $M i$. longicaudus in Alaska were moderately larger $(15 \times$ 12 [12-17.5 $\times 10-13])$ than those measured by Saxe et al. $(1960)(13 \times 10[11-15 \times 8-11])$ and by Vance and Duszynski $(1985)(13 \times 11$ [11-14 × 10-12]), but all other quantitative and qualitative features were the same. Likewise, those we measured from $\mathrm{Mi}$. pennsylvanicus in Alaska were also slightly larger $(14 \times 10$ [13-14 ×9-11]). This study represents new host and/or locality records for $\mathrm{Mi}$. longicaudus, $\mathrm{Mi}$. miurus, and Mi. oeconomus in Alaska and $\mathrm{Mi}$. oeconomus in Siberia. A line drawing (Saxe et al., 1960) and photomicrograph of sporulated oocysts (Vance and Duszynski, 1985) of E. saxei have already been published.

\section{Eimeria wenrichi Saxe, Levine, and Ivens, 1960}

Type host: Microtus pennsylvanicus Ord, 1815, meadow vole.

Other hosts: Mi. mexicanus fulviventer, Mi. m. mexicanus, Mi.m. mogollonensis, Mi. m. subsimus, Mi. montanus arizonensis, Mi. o. oregoni, Mi. p. pennsylvanicus, Mi. oeconomus, Mi. longicaudus, Mi. miurus, Mi. xanthognathus.

Collected (this study): H. Henttonen, J. Niemimea, K. Gamblin, L. B. Barrelli, 26 July 2001.

Type locality: North America: U.S.A., Pennsylvania.

Locality (this study): North America: U.S.A., Alaska, Yukon-Charley Rivers National Preserve, Eagle $\left(64^{\circ} 58^{\prime} \mathrm{N}, 143^{\circ} 3^{\prime} \mathrm{W}\right)$.

Geographic distribution: North America: U.S.A., Alaska, Arizona, Massachusetts, Washington; Mexico, Coahuila, Oaxaca, Veracruz; Asia: Russia, Siberia.

Prevalence: 1/1 (100\%) in Mi. pennsylvanicus (type species); 1/26 (4\%) in Mi. mexicanus fulviventeri from Oaxaca, 4/15 (3\%) in Mi. m. mexicanus from Veracruz, $1 / 1(100 \%)$ in Mi. m. mogollonensis from Arizona, 8/48 (8\%) in Mi. m. subsimus from Coahuila, 4/8 (50\%) in Mi. montanus arizonensis from Arizona, 2/4 (50\%) in Mi. o. oregoni from Washington, and 5/11 (45\%) in Mi. p. pennsylvanicus from Massachusetts (all from Vance and Duszynski, 1985); 3/29 (10\%) in Mi. longicaudus, 39/88 (44\%) in Mi. miurus, 265/405 (65\%) in Mi. oeconomus, $123 / 159$ (77\%) in Mi. pennsylvanicus, and $9 / 52(17 \%)$ in $\mathrm{Mi}$. xanthognathus, all from Alaska (Table 1); 29/48 (60\%) in Mi. oeconomus from Russia (Table 1).

Sporulation: $2-3$ days at $24-27^{\circ} \mathrm{C}$.

Prepatent and patent periods: Unknown.

Site of infection: Unknown, oocysts recovered from feces.

Endogenous development: Unknown.

Material deposited: A photosyntype is deposited in the USNPC as \#88517. Symbiotype host (this study), UAM 58313 (AF 49611).

Remarks: In the original description by Saxe et al. (1960) they referred to this species as "E. wenrichi species A." The morphology of oocysts from Microtus species in Alaska and Russia is similar to those reported in the original description for $E$. wenrichi from Mi. pennsylvanicus. Oocysts we measured $(N=25)$ from Mi. longicaudus in Alaska were slightly larger $(20.8 \times 15.8$ [19-23 × 14-16.5] $)$ than those measured by Saxe et al. (1960) $(18.9 \times$ 14.3 [16-22 × 12-16]), but all other quantitative and qualitative features were the same. This study represents new host and/or locality records for $\mathrm{Mi}$. longicaudus in Alaska. The oocysts we saw in the 5 Microtus species in this study (Table 1) resemble the form we call E. sp. 2 from A. macrotis (from Russia), above. A line drawing (Saxe et al., 1960) and photomicrograph of sporulated oocysts (Vance and Duszynski, 1985) of E. wenrichi have already been published.

\section{Isospora clethrionomydis Golemansky and Yankova, 1973 Fig. 6}

Type host: Myodes (C.) glareolus (Shreber, 1780), bank vole.

Other hosts: My. rufocanus (Russia), My. rutilus (Alaska), Table 1. 
Collected (this study): H. Henttonen, 25 July 2001.

Type locality: Europe: Bulgaria.

Locality (this study): North America: U.S.A., Alaska, Yukon-Charley Rivers National Preserve, near base of Mount Sorenson, north of Seventy-Mile headwaters $\left(64^{\circ} 58^{\prime} \mathrm{N}, 143^{\circ} 3^{\prime} \mathrm{W}\right)$.

Geographic distribution: Europe: Bulgaria; North America: U.S.A., Alaska; Asia: Russia, Siberia.

Prevalence: 39/109 (36\%) My. glareolus (type host) from 5 localities in Bulgaria were infected with coccidia, but is was not stated how many of the 39 were infected with I. clethrionomydis; 1/53 $(<2 \%)$ My. rufocanus (Russia); 4/699 $(<1 \%)$ My. rutilus (Alaska) (Table 1).

Sporulation: Unknown.

Prepatent and patent periods: Unknown.

Site of infection: Small intestine.

Endogenous stages: Unknown.

Material deposited: A photoneotype (see Duszynski, 1999) of a sporulated oocyst from My. rutilus (Alaska) is deposited in the USNPC as \#99502. Symbiotype host (this study), UAM 58263 (AF 49559).

Remarks: The morphology of sporulated oocysts we studied from My. rutilus in Alaska is similar to the description by Golemansky and Yankova (1973) of I. clethrionomydis from My. glareolus in Europe. Our sporulated oocysts were slightly larger than those in the original description $(27 \times 26$ vs. $25 \times 25)$, but this difference seems insignificant. Golemansky and Yankova (1973) described the sporocysts they saw as "elongated," measuring 21-23 × 11-12. However, both their line drawing and photomicrograph of a sporulated oocyst show sporocysts that are broadly ovoidal. The sporocysts we measured were $17 \times 11$ (15-18 × 10-11), L/W ratio: 1.5 , and seem more parsimonious with their original line drawing and (poor quality) photomicrograph. In the original they describe a "light-refracting Stieda body," and the drawing shows a SB much wider than high. The SB in the sporocysts we studied was approximately 4 times wider than high. Additionally we report a SSB, which Golemansky and Yankova (1973) did not mention, although there is a hint of this structure in their line drawing. The SSB we observed was clearly visible and slightly wider than the SB. The recovery of I. clethrionomydis from My. rutilus in Alaska and
My. rufocanus from Russia are new host and geographic records for this parasite.

\section{Isospora clethrionomysis Arnastauskiene and Maldzhiunaite, 1981}

Fig. 7

Type host: Myodes (C.) glareolus (Shreber, 1780), bank vole.

Other hosts: My. rutilus (Alaska), Table 1.

Collected (this study): V. B. Fedorov, 2 August 2001.

Type locality: Eastern Europe: Lithuania.

Locality (this study): North America: U.S.A., Alaska, Noatak National Preserve, near Aniralik Lake $\left(68^{\circ} 12^{\prime} \mathrm{N}, 159^{\circ} 49^{\prime} \mathrm{W}\right)$.

Geographic distribution: Eastern Europe: Lithuania; North America: U.S.A., Alaska.

Prevalence: $5 / 946(<1 \%)$ in My. glareolus (type host); 4/699 $(<1 \%)$ in My. rutilus from Alaska (this study).

Sporulation: Unknown.

Prepatent and patent periods: Unknown.

Site of infection: Unknown, oocysts recovered from feces.

Endogenous development: Unknown.

Material deposited: A photoneotype (see Duszynski, 1999) of a sporulated oocyst from My. rutilus (Alaska) is deposited in the USNPC as \#99503. Symbiotype host (this study), UAM 56434 (AF 48526).

Remarks: The morphology of oocysts from $M y$. rutilus in Alaska is similar to the original description by Arnastauskiene and Maldzhiunaite (1981) of $I$. clethrionomysis from My. glareolus in 6 districts in Lithuania. In their description only oocyst size ranges were given $(9-11 \times 7-10)$. The oocysts we measured $(N=25)(10 \times 10[9-12.5 \times 9-12])$ are slightly larger. Sporocyst size was not reported in the original description, but the line drawing shows them to be spindle shaped (slightly pointed at both ends) and almost as long as the oocyst is wide. The sporocysts we measured $(N=25)$ are of comparable size $(8 \times 5$ [7.5-8 $\times 4.5-5])$, but we also saw that they possess a small, but distinct, Stieda body not reported by Arnastauskiene and Maldzhiunaite (1981). Finally, the sporozoites we saw were sausage-shaped rather 
than the pointed, spindle-shaped ones described and drawn by Arnastauskiene and Maldzhiunaite (1981) Other qualitative features (e.g., small, membranebound SR) are similar to the original. The recovery of I. clethrionomysis from My. rutilus is a new host and geographic record in Alaska.

\section{Lemmings \\ Eimeria sp. 3}

Host: Lemmus trimucronatus Richardson, 1825 , arctic or brown lemming.

Other hosts: Lemmus lemmus L., 1758 (Table 1).

Collected: A. M. Runck, N. E. Dokuchaev, R. Foster, K. Fisher, E. Tomasik, 28 July 2001.

Locality: North America: U.S.A., Alaska, Bering Land Bridge National Preserve, Bendeleben $\left(65^{\circ} 23.4^{\prime} \mathrm{N}, 163^{\circ} 15.9^{\prime} \mathrm{W}\right)$.

Geographic distribution: Asia: Russia, Siberia; North America: U.S.A., Alaska.

Prevalence: $1 / 11$ (9\%) in L. lemmus; $2 / 72(3 \%)$ in L. trimucronatus (Table 1).

Material deposited: Symbiotype host, UAM 55562 (AF 46286).

Remarks: There are no coccidia yet described from this host species. Arnastauskee (1980) described oocysts of Eimeria chatangae from Lemmus sibiricus that were similar in size $(13-14 \times 11-13)$ to those we found in this study $(12 \times 11[10-13 \times 9-11.5])$, but his sporocysts $(8-9 \times 5-6)$ were larger than those we measured $(6 \times 4$ [4.5-6 6 3-4]), and there are qualitative differences between the species. Oocysts of E. chatangae lack a PG while the sporocysts are drawn as pointed, long structures, and do not have a SB. The sporulated oocysts we measured from L. lemmus were similar to, but smaller than, those of E. saxei first described from Mi. pennsylvanicus in Pennsylvania and later found in several other Microtus species/subspecies in 2 states in the U.S.A. and 3 states in Mexico (Vance and Duszynski, 1985). We also found similar looking sporulated oocysts in Lemmus trimucronatus $(14 \times 13$ [12-15 $\times$ $12-14]$ and $7 \times 4.5,[6-8 \times 4-5])$, which had slightly larger oocysts, but not sporocysts, than in the first description of E. saxei. In both Lemmus species, only the oocysts varied in size while the sporocysts and all structural and qualitative features were the same as in E. saxei. However, for reasons stated earlier and in our Discussion, we believe it best at this time to document its presence in $L$. lemmus and $L$. trimucronatus but not name it.

\section{Eimeria sp. 4}

Host: Lemmus trimucronatus Richardson, 1825, arctic or brown lemming.

Other hosts: None.

Collected: V. B. Fedorov, A. Fedorov, B. Wagner, E. C. Waltari, 19 July 2001.

Locality: North America: U.S.A., Alaska, Noatak National Preserve, Ambler River, Laluch Creek Upland $\left(67^{\circ} 39^{\prime} \mathrm{N}, 158^{\circ} 11^{\prime} \mathrm{W}\right)$.

Geographic distribution: North America: U.S.A., Alaska.

Prevalence: 5/72 (7\%) (Table 1).

Material deposited: Symbiotype host, UAM 56355 (AF 48310).

Remarks: The oocysts we measured were most similar to those E. subsimi first described from $M i$. mexicanus; they are also quite similar to those we call E. sp. 1 from A. macrotis. However, as already noted, we believe it best only to document its presence in $L$. trimucronatus. A line drawing and photomicrographs of sporulated oocysts of E. subsimi already have been published (Vance and Duszynski, 1985), and photosyntypes are in the USNPC as \#88512.

\section{Eimeria sp. 5}

Host: Lemmus trimucronatus Richardson, 1825, arctic or brown lemming.

Other hosts: None.

Collected: V. B. Fedorov, A. Fedorov, B. Wagner, E. C. Waltari, 20 July 2001.

Locality: North America: U.S.A.: Alaska, Noatak National Preserve, Ambler River, Kaluich Creek Upland $\left(67^{\circ} 39^{\prime} \mathrm{N}, 158^{\circ} 11^{\prime} \mathrm{W}\right)$.

Geographic distribution: North America: U.S.A., Alaska.

Prevalence: 8/72 (11\%) (Table 1).

Material deposited: Symbiotype host, UAM 56378 (AF 48335).

Remarks: The morphology of sporulated oocysts from L. trimucronatus in Alaska is very similar to the 
description provided by Upton and Pitts (1993) of Eimeria synaptomys described from Synaptomys cooperi in Missouri with oocyst $(27 \times 22[23-31 \times$ 19-24]) and sporocyst $(12 \times 8[10.5-13.5 \times 7-9])$ sizes, as well as all qualitative features nearly identical to those in the original description except that their OR was a single globule $\sim 6$, while ours was smaller, $\sim 3$. Both quantitative and qualitative features of the sporulated oocysts of Eimeria sp. 5 and of Eimeria synaptomys are similar to those of E. ochrogasteri from Microtus species (Ballard, 1970; Vance and Duszynski, 1985) with only subtle differences. Given that Synaptomys and Lemmus are sister taxa (Conroy and Cook, 1999; Jarrell and Fredga, 1993), the most parsimonious conclusion might be that these oocysts in L. trimucronatus also represent E. synaptomys. It's known from crossinfection experiments, for example, that sister taxa of other rodents, for instance, Peromyscus and Reithrodontomys species, are capable of sharing coccidia species (Upton et al., 1992; Hnida and Duszynski, 1999a). However, we believe it best only to document its presence in L. trimucronatus until molecular evidence can clear up this picture to set the record straight (see Remarks, Eimeria sp. 1, and Discussion, below). A line drawing and photomicrographs of sporulated oocysts of E. synaptomys already have been published (Upton and Pitts, 1993).

\section{Eimeria sp. 6}

Host: Synaptomys borealis Richardson, 1828, bog lemming.

Other hosts: None, see Remarks, below.

Collected: H. Henttonen, J. Niemimea, A. V. Goropashnaya, J. Burch, 8 August 2001.

Locality: North America: U.S.A., Alaska, YukonCharley Rivers National Preserve, across Yukon River from Glenn Creek cabin $\left(65^{\circ} 18^{\prime} \mathrm{N}, 142^{\circ} 14^{\prime} \mathrm{W}\right)$.

Geographic distribution: North America: U.S.A., Alaska.

Prevalence: 4/187 (2\%) (Table 1).

Material deposited: Symbiotype host, UAM 60299 (AF 49479).

Remarks: The oocysts we measured $(13.5 \times 12$ [11$16 \times 10-13.5])$ most closely resemble those of E. saxei described from Microtus species in Pennsylvania, California, and Washington, U.S.A., and from Oaxaca, Mexico, and Coahulia, Mexico (Saxe et al., 1960;
Vance and Duszynski, 1985); they also resemble the oocysts we found in Mi. longicaudus and Mi. pennsylvanicus and Eimeria sp. 3 from L. lemmus in this study (Table 1). It may be possible that this species is actually E. saxei, capable of infecting multiple host genera that are closely related, but we believe it best at this time only to document its presence in $S$. borealis and wait until molecular data can provide evidence that this is either one or multiple species.

\section{Eimeria sp. 7}

Host: Synaptomys borealis Richardson, 1828, bog lemming.

Other hosts: None, see Remarks, below.

Collected: S. O. MacDonald, A. N. Lazutkin, A. J. Lynch, S. Runck, 24 July 2001.

Locality: North America: U.S.A., Alaska, YukonCharley Rivers National Preserve, Charley River, $12.5 \mathrm{~km}$ east-northeast of Kathul Mountain $\left(65^{\circ} 22^{\prime} \mathrm{N}\right.$, $\left.142^{\circ} 01^{\prime} \mathrm{W}\right)$.

Geographic distribution: North America: U.S.A., Alaska.

Prevalence: 17/187 (9\%) (Table 1).

Material deposited: Symbiotype host, UAM 57419 (AF 52076).

Remarks: Oocysts we measured $(30 \times 20[28-32 \times$ 17.5-22]) seemed most similar to those of E. subsimi described from Mi. mexicanus from Mexico (Vance and Duszynski, 1985) and were quite similar to Eimeria sp. 1 from A. macrotis from Russia (this study) and Eimeria sp. 4 from L. trimucronatus from Alaska (this study). Because of rapid host speciation (Conroy and Cook, 1999), we could suggest that this species may be able to infect multiple host genera; however, we believe it best only to document its presence in S. borealis and wait until molecular data can provide evidence that this is either one or multiple species. A line drawing and photomicrographs of sporulated oocysts of E. subsimi already have been published (Vance and Duszynski, 1985), and photosyntypes are in the USNPC as \#88512.

\section{Eimeria synaptomys Upton and Pitts, 1993 Fig. 8}

Type host: Synaptomys cooperi Baird, 1858, bog lemming. 
Other hosts: Synaptomys borealis Richardson, 1828.

Collected (this study): H. Henttonen, J. Niemimea, K. Gamblin, L. B. Barrelli, 27 July 2001.

Type locality: North America: U.S.A., Missouri, St. Charles County, 3.4 km West Weldon Spring.

Locality (this study): North America: U.S.A., Alaska, Yukon-Charley Rivers National Preserve, at base of Mount Sorenson, north of Seventy-Mile headwaters $\left(64^{\circ} 58^{\prime} \mathrm{N}, 143^{\circ} 3^{\prime} \mathrm{W}\right)$.

Geographic distribution: North America: U.S.A., Alaska, Missouri.

Prevalence: $2 / 22$ (9\%) in S. cooperi (type host); $9 / 187$ (5\%) in S. borealis (Table 1).

Sporulation: Unknown.

Prepatent and patent periods: Unknown.

Site of infection: Unknown, oocysts recovered from feces.

Endogenous development: Unknown.

Material deposited: A photoneotype (see Duszynski, 1999) of a sporulated oocyst is deposited in the USNPC as \#99501. Symbiotype host (this study), UAM 58343 (AF 49647).

Remarks: The oocysts and sporocysts we measured were similar to those seen in the original description by Upton and Pitts (1993). These oocysts also were similar to those of Eimeria sp. 5 that we found in L. trimucronatus. A line drawing and photomicrographs of sporulated oocysts of $E$. synaptomys already have been published (Upton and Pitts, 1993).

\section{Eimeria sp. 8}

Host: Synaptomys borealis Richardson, 1828, bog lemming.

Other hosts: None, see Remarks, below.

Collected: S. Kutz, A. A. Tsvetkova, A. A. Eddingsaas, M. McCain, 4 August 2001.

Locality: North America: U.S.A., Alaska, Wrangell-St. Elias National Park and Preserve, Harry's Gulch $\left(61^{\circ} 3.8^{\prime} \mathrm{N}, 143^{\circ} 54^{\prime} \mathrm{W}\right)$.

Geographic distribution: North America: U.S.A., Alaska.

Prevalence: 4/187 (2\%) (Table 1.)
Material deposited: Symbiotype host, UAM 56004 (AF 53552).

Remarks: The oocysts $(21 \times 15$ [20-24×13-16]) and sporocysts $(11 \times 6[10-12 \times 5-7.5])$ we measured were similar to those seen in the original description of E. wenrichi (species "A") from 1 Mi. pennsylvanicus collected in Pennsylvania, U.S.A. (Saxe et al., 1960; Vance and Duszynski, 1985). They also are similar to oocysts we identify as E. wenrichi from Microtus species in this study and to Eimeria sp. 2 in A. macrotis from Siberia in this study. As stated, we believe it best at this time to record its presence in $S$. borealis and wait until further study can provide evidence that this is either one or multiple species. A line drawing (Saxe et al., 1960) and photomicrograph of sporulated oocysts (Vance and Duszynski, 1985) of E. wenrichi have already been published, and photosyntypes are in the USNPC as \#88517.

\section{DISCUSSION}

This study compares the coccidia of closely related rodent taxa separated by a geographic barrier, the Bering Strait. Rodentia is the most speciose order of mammals and occupies a wide variety of habitats. Because of their virtual ubiquity on land, we know more about the coccidia of rodents than we do about those of any other mammalian order (Duszynski and Upton, 2001). Nonetheless, $<15 \%$ of the 2,277 rodent species (Wilson and Reeder, 2005) have been examined for coccidia.

In spite of the paucity of information, the picture that emerges is that the degree of host specificity seems to vary from host group to host group. For example, in murid rodents of the subfamily Sigmodontinae, Reduker et al. (1987) recovered a similar eimerian morphotype, "type A," across multiple host genera (Peromyscus, Neotoma, and later Baiomys, Onychomys, and Reithrodontomys [Upton et al., 1992]). However, when the "type A" morphotypes were subjected to cross-infection experiments (Hnida and Duszynski, 1999a, Upton et al., 1992) and DNA sequencing (Hnida and Duszynski, 1999b), each host was found to have a different species of Eimeria.

Conversely, in sciurids (squirrels and their relatives), some experimental evidence (Todd and Hammond, 1968a, b; Thomas and Stanton, 1994) suggests eimerians may easily switch between host species in closely related genera, and an eimerian from the chinchilla is known to infect 7 genera of mammals in 2 families (DeVos, 1970). Work by Hafner (1984) suggested that sciurids differentiated in 
the Pleistocene and that many may be able to harbor similar parasites. Based on these efforts, Wilber et al. (1998) decided to use the "morphological species concept" to revise and summarize the coccidia of the Marmotini, the largest tribe within the Sciuridae. Recently this approach also has been used by others (e.g., Seville et al., 2005).

Phylogenetic work by Conroy and Cook (1999) suggested rapid pulses of speciation in arvicoline rodents due to a series of unresolved polytomies found at several periods in the arvicoline radiation. Many of the same rodent taxa in their analyses were surveyed in this study, and the coccidia we identified by their sporulated oocysts are consistent with a rapid speciation process in these rodents because similar oocyst morphotypes were found across both genera and species in geographically sympatric host taxa. Thus, the question becomes what should we do with the oocyst morphotypes we find in these genera and species, most of which closely resemble "species" described from other host genera. On one hand, our results may suggest that these high-latitude arvicoline rodents have Eimeria that are able to cross generic boundaries. Hoberg et al. (2003) suggested that drivers for speciation for the rodents collected in this study might be different than those for other rodents, which, in turn, might influence the speciation patterns among parasitic protists and other parasites. On the other hand, Tenter et al. (2002) said that without multiple lines of evidence, for instance, mensural and molecular data, coccidia that are morphologically indistinguishable and identified from closely related hosts should not be described as new species. Thus, we believe the most prudent choice is to name new species (e.g., E. rutilus) only when we feel the morphological mensural data are sufficiently different from all other eimerians described from related host species to warrant new taxon status. In all other instances, such as in the other morphotypes we saw (Eimeria spp. 1-8), we only mention their presence and point out the similarities to their closest structural relatives.

Myodes is a Holarctic genus composed of 9 Palearctic, 2 Nearctic, and 1 Holarctic species (Wilson and Reeder, 2005). Prior to this study, 3 species, My. gapperi, My. glareolus, and My. rutilus, had been surveyed for coccidia (Levine and Ivens, 1990). Levine and Ivens (1990) recognized E. cernae and E. rysavyi from the bank vole, My. glareolus, in Czechoslovakia, and Arnastauskiene (1977) reported E. cernae and described Eimeria schiwicki from My. rutilus in Russia. In North America Straneva and Kelley (1979) described and named 4 coccidia from the southern red-backed vole, My. gapperi: E. clethrionomyis, E. gallattii, E. marconii, and E. pileata. Here we found coccidia from My. rufocanus and My. rutilus that have been previously reported from Old World My. glareolus and New World My. gapperi. We also discovered a new coccidium, E. rutilus, in My. rufocanus and My. rutilus. A recent phylogenetic tree created with the cytochrome b gene suggests that My. gapperi is more closely related to My. glareolus than to My. rutilus, and all 3 are more closely related to one another than they are to $M y$. rufocanus (Cook et al., 2004). It is interesting to note that 2 coccidia, E. clethrionomyis and E. pileata, identified by Straneva and Kelley (1979) from My. gapperi, were not recovered in this study.

The genus Microtus has 65 species; 44 are Palearctic, 20 Nearctic, and 1 (Mi. oeconomus) is Holarctic in distribution (Wilson and Reeder, 2005). To date, 36 species of Eimeria and 3 species of Isospora have been described from Microtus. The majority of these species (29 Eimeria, 1 Isospora) are described from Eurasian Microtus spp., while all the coccidia reported from the 5 species of Microtus in this study were similar to coccidia reported from North America. Conroy and Cook (2000) suggested endemic species of North American Microtus are monophyletic and that $M i$. oeconomus is a recent immigrant ( $>55,000$ years) to North America via the BLB (Galbreath and Cook, 2004). Of the 5 Microtus spp. we examined, only Mi. pennsylvanicus had been surveyed previously for coccidia. We expected to find coccidia in the 4 North American Microtus spp. (Table 1) that were similar to those in other Microtus spp. in North America (see Vance and Duszynski, 1985; Ballard, 1970) and coccidia in Mi. oeconomus (a Eurasian species) that would be similar to coccidia described from Eurasian Microtus spp. Instead, we found Mi. oeconomus on both continents infected by the same species of coccidia that infect the North American endemic species (Table 1).

Other genera included in this study have had few coccidia reported from them: Alticola, E. bassagensis; Dicrostonyx, E. dicrostonicis; Lemmus, E. chatangae and E. nativa; and Synaptomys, E. synaptomys (Levine and Ivens, 1990). Our results suggest that 3 of these 4 host genera were infected with coccidia that discharged oocysts quite similar in their morphology to those seen previously to infect the genus Microtus.

The data from arvicoline rodents may be interpreted at least 2 ways. It is possible that several of their eimeriid coccidia (E. saxei, E. subsimi, E. synaptomys, E. wenrichi) are temporally, ecologically, 
and genetically the same species of generalist coccidia found across multiple host taxa. For example, oocysts of E. saxei from Microtus are similar to the oocysts of Eimeria spp. 3 and 6 from Lemmus and Synaptomys, respectively. Similarly oocysts of E. subsimi (Microtus) resemble Eimeria spp. 1 (Alticola), 4 (Lemmus), and 7 (Synaptomys); those of E. synaptomys (Synaptomys) resemble Eimeria sp. 5 (Lemmus); and those of E. wenrichi (Microtus) resemble those of Eimeria sp. 2 (Alticola) and 8 (Synaptomys). This interpretation suggests there have been insufficient selective pressure and/or time for these coccidia to speciate. While each of these hosts is not sympatric with all of the other hosts and there is fine-scale niche partitioning (see Getz [1985] for Microtus and Linzey [1984] for data on Synaptomys and Microtus), their combined ranges are contiguous (see trap line data sheets for Beringia Coevolution Project stored at the University of AlaskaFairbanks and the University of New Mexico). It is possible, then, that there is flow of coccidia across host genera. The other interpretation is that morphologically similar oocysts are indeed different species in different hosts. The oocysts identified here with similar morphology in multiple host genera may instead each be different species representing distinct lineages that reflect host relationships. The idea of cryptic speciation (i.e., speciation without obvious morphological divergence) has been suggested as characterizing the parasites of Arctic arvicoline rodents because long-term climatic oscillations have caused repeated fragmentation and isolation as well as subsequent divergence, especially in lemming and vole populations (Fedorov et al., 1999; Fedorov and Goropashnaya, 1999; Hoberg et al., 1999). In fact, Haukisalmi et al. (2004) documented multiple species of cestodes hidden by their apparent morphological similarity to Paranoplocephala omphalodes, a Holarctic parasite of Microtus voles in Alaska, Russia, and elsewhere, and Baverstock et al. (1985) showed that another cestode thought to be a host-generalist parasite of wombats, wallabies, and kangaroos includes at least 12 biological species that are strictly host specific when isozyme electrophoretic data were examined. DNA sequence data in the form of Eimeria gene phylogenies or population-level microsatellite work on Eimeria spp. from these host groups may provide us with answers to these enigmatic observations.

Since the advent of phylogenetic reconstructions, innumerable schemes have been proposed for various families and genera within the order Rodentia. Homoplasy among morphological characters has made it difficult to discern a consistent interpretation of relationships among the 29 families. Recently Debry (2003) combined data from multiple genes to analyze familial relationships. His (2003) work suggests there are 2 distinct clades. One contains Myodonta (Muroidea plus sister taxa Dipodidae), Geomyoidea, Pedetidae, and Castoridae, while the other clade is composed of Sciuroidea, Gliridae, and Hystricognathi.

Here, based on morphology of the sporulated oocysts, one interpretation suggests that coccidia in arvicoline rodents (family Cricetidae, superfamily Muroidea) may be able to infect multiple genera much like the coccidia in sciurids. Based on Debry's (2003) work, these 2 groups of rodent hosts aren't closely related. However, the fossil record and molecular data support a rapid arvicoline radiation (Conroy and Cook, 1999), much like the sciurids (Hafner, 1984). This speciation alone may be enough to explain the similarity in the ability of some Eimeria spp. to infect multiple host genera. If this is the case, then other groups of rodents (and possibly other mammals) that have undergone rapid speciation also may have multiple genera infected by similar coccidia.

Additionally, host ecology certainly affects transmittance of coccidia between individuals sharing an environment. Many sciurid rodents are highly social and dwell in subterranean tunnels (Murie and Michener, 1984). Harsh weather conditions that may affect coccidia transmission may be mitigated by the microclimates created by burrows (Thomas et al., 1995). Also, sympatry of many grounddwelling sciurids would help to create and maintain a guild of hosts sharing the same coccidia (Shults et al., 1990). In general, voles and lemmings aren't as social as sciurids; however, they utilize runways and create shallow burrows that multiple vole and lemming species use (Gromov and Polyakov, 1992). Hertel and Duszynski (1987) suggested that, at least for shrews, similar habitat conditions (runways and burrows) might be conducive to oocyst transmission. The similarity of habitat usage creates a flow of oocysts across multiple host species that might inhibit parasite speciation.

Of the 1,925 cricetid specimens, 68 (3.5\%) harbored multiple infections with coccidia; 65 with 2 species and 3 were infected with 3 coccidia simultaneously. Of those, 23 were double infections and 2 were triple infections of coccidia in My. rutilus. The majority of double infections (17) were composed of E. cernae with E. marconii. The rest (6) were E. cernae with E. rutilus. One triple infection 
was composed of E. cernae, E. marconii, and E. rutilus, while the other had $I$. clethrionomysis rather than E. marconii. There were 42 Microtus spp. that were host to infections of 2 coccidia: Mi. longicaudus, 1; Mi. miurus, 1; Mi. pennsylvanicus, 16; and Mi. oeconomus, 24. Both Mi. longicaudus and $M i$. miurus had 1 infection of $E$. saxei with $E$. wenrichi. In Mi. oeconomus, infections were composed of E. wenrichi with E. saxei (13), E. wenrichi with E. subsimi (8), and E. wenrichi with $E$. ochrogasteri (3). In Mi. pennsylvanicus there were equal numbers of infections of $E$. wenrichi with $E$. saxei (8) and E. wenrichi with E. subsimi (8). Only 1 specimen of Mi. pennsylvanicus harbored 3 coccidia: E. wenrichi, E. saxei, and E. subsimi. No other murids were host to multiple infections.

Three previous studies on the coccidia of $Z$. hudsonius reported 2 species of Eimeria (Levine and Ivens, 1990). The prevalence of coccidia across these 3 studies varied considerably. Duszynski et al. (1982) reported a prevalence of 6\% (2/35); Gerard et al. (1977), 80\% (4/5); and Whitaker (1963), 23\% (7/31). It seems unusual that no coccidia were found in the 15 samples we collected. Including this study, there have been no reports of coccidia from the Erethizontidae.

\section{ACKNOWLEDGMENTS}

Thanks are due the field teams in Alaska and Russia who made this work possible; in particular we thank L. B. Barrelli, J. Burch, N. E. Dokuchaev, A. A. Eddingsaas, A. Fedorov, V. B. Fedorov, K. Fisher, R. Foster, K. E. Galbreath, K. Gamblin, A. V. Goropashnaya, H. Henttonen, S. Kutz, A. N. Lazutkin, N. MacDonald, N. I. MacDonald, S. O. MacDonald, M. McCain, J. Niemimea, A. M. Runck, S. Runck, E. Tomasik, A. A. Tsvetkova, B. Wagner, E. C. Waltari, and all the others. This work was supported by NSF-DEB Grant \#0196095, the Beringian Coevolution Project (to JAC, E. P. Hoberg), and a subcontract on DEB \#0196095 to UNM, Coevolution of insectivores and their coccidia parasites in Beringia (to DWD).

\section{LITERATURE CITED}

Arnastaukiene, T. V. 1977. K voprosy o zarazhennosti zhivotnykh koktsidiyami Taimyre [The question about contamination by coccidia of animals on Taimyr]. Pages 135-143 in G. V. Kornulova, V. K. Yastrebov, and V. A. Klebanevskii, eds. Problemy Epidemiologii Profilaktiki Prirodnoochagovykh Boieznei v Zapolyar'e Ministerstvo Zdravookhraiieniya RSFSR.
Omskii Ordena Trudovogo Krasnogo Znameni Meditsinskii Institut, Omsk, USSR.

Arnastaukiene, T. V. 1980. Kharakteristika zarazhennosti melkikh miekopitayushchikh koktsidiyami naTimyrev 1974-1975 [Characteristics of the infection of small mammals with coccidia in the Taimir Peninsula in 1974-1975]. T. Akadamie Nauk Litovskoi SSR Ser. B 2:53-60.

Arnastaukiene, T. V., and S. Maldziunaite. 1981. Fauna and its groupings of coccidia of the bank voles of Lithuania. Acta Parasitologica Lituanica 19:36-41 (in Russian).

Ballard, N. B. 1970. Eimeria ochrogasteri n. sp. from the prairie vole, Microtus ochrogaster. Journal of Protozoology 17:271-273.

Bandoni, S. M., and D. W. Duszynski. 1988. A plea for improved presentation of type material for coccidia. Journal of Parasitology 74:519-523.

Baverstock, P. R., M. Adams, and I. Beveridge. 1985. Biochemical differentiation in bile duct cestodes and their marsupial hosts. Molecular Biology and Evolution 2:321-337.

Brooks, D. R. 1993. Critical comment: extending the symbiotype concept to host voucher specimens. Journal of Parasitology 79:631-633.

Conroy, C. J., and J. A. Cook. 1999. MtDNA evidence for repeated pulses of speciation within Arvicolinae and murid rodents. Journal of Mammalian Evolution 6: 221-245.

Conroy, C. J., and J. A. Cook. 2000. Molecular systematics of a holarctic rodent (Microtus: Muridae). Journal of Mammalogy 81:344-359.

Cook, J. A., E. P. Hoberg, A. Koehler, S. O. MacDonald, H. Henttonen, L. Wickstrom, V. Haukisalmi, K. Galbreath, F. Chernyavski, N. Dokuchaev, A. Lahzuhtkin, A. Hope, E. Waltari, A. Runck, A. Veitch, R. Popko, E. Jenkins, S. Kutz, and R. Eckerlin. 2005. Beringia: intercontinental exchange and diversification of high latitude mammals and their parasites during the Pliocene and Quaternary. Mammal Science 30:S33-S44.

Cook, J. A., A. M. Runck, and C. J. Conroy. 2004. Historical biogeography at the crossroads of the northern continents: molecular phylogenetics of redbacked voles (Rodentia: Arvicolinae). Molecular Phylogenetics and Evolution 30:767-777.

Debry, R. W. 2003. Identifying conflicting signal in a multigene analysis reveals a highly resolved tree: the phylogeny of Rodentia (Mammalia). Systematic Biology 52:604-617.

De Vos, A. J. 1970. Studies on the host range of Eimeria chinchillae (De Vos and Van der Westhuizen, 1968). Ondersteeport Journal of Veterinary Research 37:2936.

Duszynski, D. W. 1999. Revisiting the Code: clarifying name-bearing types for photomicrographs of protozoa. Journal of Parasitology 85:769-770.

Duszynski, D. W. 2002. Coccidia (Apicomplexa: Eimeriidae) of the Mammalian Order Chiroptera. Special Publication of the Museum of Southwestern Biology, No. 5, First Impressions Inc., Albuquerque, New Mexico, p. 1-45.

Duszynski, D. W., G. Eastham, and T. L. Yates. 1982. Eimeria from jumping mice (Zapus spp.): a new 
species and genetic and geographic features of Z. hudsonius luteus. Journal of Parasitology 68: 1146-1148.

Duszynski, D. W., and S. J. Upton. 2001. Cyclospora, Eimeria, Isospora, and Cryptosporidium spp. Pages 416-459 in W. M. Samuel, M. J. Pybus, and A. A. Kocan, eds. Parasitic Diseases of Wild Mammals, 2nd ed. Iowa State University Press, Ames, Iowa.

Duszynski, D. W., and P. G. Wilber. 1997. A guideline for the preparation of species descriptions in the Eimeriidae. Journal of Parasitology 83:333-336.

Dzerzhinskii, V. A., and S. K. Svanbaev. 1980. Coccidia of rodents in the foothills of the Zailiiskii Altai mountains, Kazakhastan SSR. IX Konference Ukrain Parasitologii Obshchestva, Tezisy Dokladov Chavst'z, Keive, USSR “Naukova Dumka”" 2:20-21.

Fedorov, V. B., and A. V. Goropashnaya. 1999. The importance of ice ages in diversification of Arctic collared lemmings (Dicrostonyx): evidence from the mitochondrial cytochrome $\mathrm{b}$ region. Hereditas 130: 301-307.

Fedorov, V. B., A. V. Goropashnaya, G. H. Jarrell, and K. Fredaga. 1999. Phylogeographic structure and mitochondrial DNA variation in ture lemmings (Lemmus) from the Eurasian Arctic. Biological Journal of the Linnean Society 66:357-371.

Frey, J. K., T. L. Yates, D. W. Duszynski, W. L. Gannon, and S. L. Gardner. 1992. Designation and curatorial management of type host specimens (symbiotypes) for new parasite species. Journal of Parasitology 78: 930-932.

Galbreath, K. E., and J. A. Cook. 2004. Genetic consequences of Pleistocene glaciations for the tundra vole (Microtus oeconomus) in Beringia. Molecular Ecology 13:135-148.

Gerard, G., B. Chobotar, and J. V. Ernst. 1977. Eimeria zapi sp. n. from the meadow jumping mouse, Zapus hudsonius Zimmerman in southwestern Michigan. Journal of Protozoology 24:362-363.

Getz, L. L. 1985. Habitats. Pages 286-309 in R. H. Tamarin, ed. Biology of New World Microtus. Special Publications no. 8. American Society of Mammalogists, Washington, D.C.

Golemansky, V., and P. Yankova. 1973. Izsledvaniya v'rkhu vidoviya s'stav i razprostranenieto na Koktsidite (Sporozoa, Coccidia) po nyako drebni bozainitsi v B'lgariya. [Studies on the species composition and occurrence of Coccidia (Sporozoa, Coccidia) in some small mammals in Bulgaria]. Investiya Zoologicheski Institutoi Muzei B'lgariyaist Akedemii Nauk 37:5-31

Gromov, I. M., and I. Y. A. Polyakov. 1992. Voles (Microtinae). D. Seigel-Causey and R. S. Hoffman, eds. Onyx Publishers, New Delhi, India. 725 pp.

Hafner, D. J. 1984. Evolutionary relationships of the nearctic Sciuridae. Pages 1-23 in J. O. Murie and G. R. Michener, eds. The Biology of Ground-Dwelling Squirrels: Annual Cycles, Behavioral Ecology, and Sociality. University of Nebraska Press, Lincoln, Nebraska.

Haukisalmi, V., L. M. Wickström, H. Henttonen, J. Hantula, and A. Gubányi. 2004. Molecular and morphological evidence for multiple species within Paranoplocephala omphalodes (Cestoda, Anoploce- phalidae) in Microtus voles (Arvicolinae). Zoologica Scripta 33:277-290.

Hertel, L. A., and D. W. Duszynski. 1987. Coccidian parasites (Apicomplexa: Eimeriidae) from insectivores. III. Seven new species in shrews (Soricidae: Soricinae) from Canada, Japan, and the United States. Journal of Parasitology 73:172-183.

Hnida, J. A., and D. W. Duszynski. 1999a. Crosstransmission studies with Eimeria arizonensis, E. arizonensis-like oocysts and E. langebarteli: host specificity with the Muridae and other rodents. Journal of Parasitology 85:873-877.

Hnida, J. A., and D. W. Duszynski. 1999b. Taxonomy and systematics of some Eimeria species of murid rodents as determined by the ITS1 region of the ribosomal gene complex. Parasitology 119:349-357.

Hoberg, E. P., S. J. Kutz, K. E. Galbreath, and J. A. Cook. 2003. Arctic biodiversity: from discovery to faunal baselines-revealing the history of a dynamic ecosystem. Journal of Parasitology 89(supplement): S84-S95.

Hoberg, E. P., K. J. Monsen, S. Kutz, and M. S. Blouin. 1999. Structure, biodiversity, and historical biogeography of nematode faunas in Holarctic ruminants: morphological and molecular diagnoses for Teladorsagia boreoarcticus $\mathrm{n}$. sp. (Nematoda: Ostertagiinae), a dimorphic cryptic species in muskoxen (Ovibos moschatus). Journal of Parasitology 85:910-934.

Jarrell, G. H., and K. Fredga. 1993. How many kinds of lemmings? Pages 45-57 in The Biology of the Lemmings. Linnean Society of London, London, United Kingdom.

Levine, N. D., and V. Ivens. 1965. The coccidian parasites (Protozoa: Sporozoa) of rodents. Illinois Biological Monograph No. 33. University of Illinois Press, Urbana, Illinois. 365 pp.

Levine, N. D., and V. Ivens. 1990. The Coccidian Parasites of Rodents, 2nd ed. CRC Press, Boca Raton, Florida. 228 pp.

Lewis, D. C., and S. J. Ball. 1982. The life-cycle of Eimeria cernae Levine and Ivens, 1965 in the bank vole, Myodes glareolus. Parasitology 85:443-449.

Lewis, D. C., and S. J. Ball. 1983. Species of Eimeria of small wild rodents from the British Isles, with descriptions of two new species. Systematic Parasitology 5:259-270.

Linzey, A. V. 1984. Patterns of coexistence in Synaptomys cooperi and Microtus pennsylvanicus. Ecology 65: 382-393.

Murie, J. O., and G. R. Michener (eds.). 1984. The Biology of Ground-Dwelling Squirrels: Annual Cycles, Behavioral Ecology, and Sociality. University of Nebraska Press, Lincoln, Nebraska. 459 pp.

Reduker, D. W., D. W. Duszynski, and T. L. Yates. 1987. Evolutionary relationships among Eimeria spp. (Apicomplexa) infecting cricetid rodents. Canadian Journal of Zoology 65:722-735.

Saxe, L. H., N. D. Levine, and V. Ivens. 1960. New species of coccidia from the meadow mouse, Microtus pennsylvanicus. Journal of Protozoology 7:61-63.

Seville, R. S., C. E. Oliver, A. J. Lynch, M. C. Bryant, and D. W. Duszynski. 2005. Eimeria species (Apicomplexa: Eimeriidae) from arctic ground squirrels (Spermophilus parryii) and red squirrels (Tamiasciurus 
hudsonicus) in Alaska and Siberia, Russia. Journal of Parasitology 91:857-862.

Shults, L. M., R. S. Seville, N. L. Stanton, and G. E. Menkens, Jr. 1990. Eimeria sp. (Apicomplexa: Eimeriidae) from Wyoming ground squirrels (Spermophilus elegans) and white-tailed prairie dogs (Cynomys leucurus) in Wyoming. Great Basin Naturalist 50:327-331.

Straneva, J. E., and G. L. Kelley. 1979. Eimeria clethrionomyis sp. n., Eimeria gallatii sp. n., Eimeria pileata sp. n. and Eimeria marconii sp. n. from the redbacked vole Myodes gapperi Vigors, from Pennsylvania. Journal of Protozoology 26:5530-5532.

Svanbaev, S. K. 1956. Materialy k faune koktsidiu dikikh mlekopitayushchikn Zapadnogo Kaszkhstana [Coccidia of wild mammals of Western Kazakhstan]. Trudy Instituta zoologii Akadamia Nauk Kazakhstan SSR 5: 180-191.

Svanbaev, S. K. 1958. K poznaniyu fauny koktsidiu gryzunov tsentral'nogo Kaszkhstana [Coccidia of rodents of Central Kaszkhstan]. Trudy Instituta Zoologii Akadamia Nauk Kazakhstan SSR 9:183-186.

Svanbaev, S. K. 1969. Koktsidii Dikikh Zhivotnykh Kazakhstana [Coccidia of Wild Animals in Kazakhstan]. Izdatelbstrivo Akademii Nakova, Kazakhstan "Nauka," Kazakhstan SSR, Alma-Ata, Kazakhstan, USSR. 212 pp.

Tenter, A. M., J. R. Barta, I. Beveridge, D. W. Duszynski, H. Mehlhorn, D. A. Morrison, R. C. A. Thompson, and P. A. Conrad. 2002. The conceptual basis for a new classification of the coccidia. International Journal for Parasitology 32:595-616.

Thomas, D. M., and N. L. Stanton. 1994. Eimerian species (Apicomplexa: Eimeriidae) in Gunninson's prairie dog (Cynomys gunnisoni zuniensis) and rock squirrels (Spermophilus variegatus grammurus) from southeastern Utah. Journal of the Helminthological Society of Washington 61:17-21.

Thomas, D. M., N. L. Stanton, and R. S. Seville. 1995. A stable eimerian assemblage in Wyoming ground squirrels (Spermophilus elegans elegans): maintaining viability over winter. Journal of the Helmintological Society of Washington 62:1-5.

Todd, K. S., Jr., and D. M. Hammond. 1968a. Life cycle and host specificity of Eimeria callospermophili Henry, 1932, from the Uinta ground squirrel, Spermophilus armatus. Journal of Protozoology 15:1-8.

Todd, K. S., Jr., and D. M. Hammond. 1968b. Life cycle and host specificity of Eimeria larimerensis Vetterling, 1964, from the Uinta ground squirrel, Spermophilus armatus. Journal of Protozoology 15:268-275.

Upton, S. J., C. T. McAllister, D. B. Brillhart, D. W. Duszynski, and C. D. Wash. 1992. Cross-transmission studies with Eimeria arizonensis-like oocysts (Apicomplexa) in new world rodents of the genera Baiomys, Neotoma, Onychomys, Peromyscus, and Reithrodontomys (Muridae). Journal of Parasitology 78:406-413.

Upton, S. J., and R. M. Pitts. 1993. A new species of coccidian (Apicomplexa: Eimeriidae) from Synaptomys cooperi (Rodentia: Muridae) in Missouri. Texas Journal of Science 45:311-314.

Vance, T. L., and D. W. Duszynski. 1985. Coccidian parasites (Apicomplexa: Eimeriidae) of Microtus spp. (Rodentia: Arvicolidae) from the United States, Mexico and Japan, with descriptions of five new species. Journal of Parasitology 71:302-311.

Whitaker, J. O., Jr. 1963. A study of the meadow jumping mouse, Zapus hudsonius (Zimmerman), in central New York. Ecological Monographs 33:215-254.

Wilber, P. G., D. W. Duszynski, S. J. Upton, R. S. Seville, and J. O. Corliss. 1998. A revision of the taxonomy and nomenclature of the Eimeria spp. Apicomplexa: Eimeriidae) from rodents in the Tribe Marmotini (Sciuridae). Systematic Parasitology 39:113-135.

Wilson, D. E., and D. M. Reeder (eds.). 2005. Mammal Species of the World: A Taxonomic and Geographic Reference, 3rd ed. Johns Hopkins University Press, Baltimore, Maryland. 2,142 pp. 